0

\title{
Specification of sewage sludge arising from a domestic wastewater treatment plant for agricultural uses
}

\author{
Walid Boumalek ${ }^{\mathrm{a}, *}$, Ahmed Kettab ${ }^{\mathrm{a}}$, Nabila Bensaciab ${ }^{\mathrm{b}}$, Maria C. Bruzzonitic, \\ Dorsaf Ben Othman ${ }^{\mathrm{d}}$, Laila Mandie, M. Nacer Chabaca ${ }^{\mathrm{f}}$, Salim Benziada ${ }^{\mathrm{a}}$ \\ 'Laboratoire de Recherche des Sciences de l'Eau, Département Hydraulique, Ecole Nationale Polytechnique d'Alger (ENP), 10, \\ Av Hacene Badi, PB 182, El-Harrach, Algiers, Algeria, Tel. +213 674754 457; emails: walid-boumalek@hotmail.com (W. Boumalek), \\ kettab@yahoo.fr(A.Kettab),benziada@yahoo.fr (S. Benziada) \\ ${ }^{b}$ Laboratoire de chimie physique moléculaire et macromoléculaire, département de chimie industrielle, faculté des sciences de l'ingénieur, \\ Université Saâd-Dahlab de Blida, BP 270, route de Soumâa, 09000 Blida, Algeria, email: polyadsorption@yahoo.fr \\ 'Department of Analytical Chemistry, University of Torino, Via P. Giuria 5, 10125 Torino, Italy, \\ email: mariaconcetta.bruzzoniti@unito.it \\ ${ }^{d}$ Geochemistry Laboratory, Sciences Faculty of Tunis, Department of Geology, Tunis El Manar University, 2092 Tunis, Tunisia, \\ email: dorbothm@yahoo.fr \\ ${ }^{e}$ National Centre for Studies and Research on Water and Energy (CNEREE), University Cadi Ayyad, Avenue Moulay Abdellah, \\ BP 511, 40000 Marrakech, Morocco, email: mandi@uca.ma \\ 'Département du génie rural, Ecole nationale supérieure agronomique (ENSA), Rue Hassen Badi Belfort, El Harrach, \\ 1600 Alger, Algérie, email: chabacam@yahoo.fr
}

Received 26 May 2018; Accepted 29 November 2018

\begin{abstract}
A B S T R A C T
The application of sewage sludge for fertilization purposes and soil amendment is arousing great interest within the scientific community in the last few years especially as the consumption of commercial fertilizers is continuously increasing and most farmers could not bear the additional cost in the rise in fertilizer prices. The objective of this research is to study the specification of sewage sludge from drying beds of Jijel wastewater treatment plant, dewatered by natural evaporation in order to assess its potential for agricultural reuse as a soil amendment. It is a sludge resulting from the secondary treatment of domestic sewage by activated sludge processes (biological treatment). A good characterization of sewage sludge goes through several steps to assess its quality and its compliance with the established requirements and guidelines for agricultural valorization in Algeria. Physicochemical analysis showed that the sewage sludge contains significant quantities of major nutrients $(\mathrm{N}, \mathrm{P}, \mathrm{K})$ and moderate amounts of secondary nutrients $(\mathrm{Ca}, \mathrm{Mg}$, S), It is generally rich in organic matter with an average of $41.2 \%$. The most harmful heavy metals $(\mathrm{Cu}, \mathrm{Cr}, \mathrm{Ni}, \mathrm{Pb}, \mathrm{Cd}, \mathrm{Se}$, and $\mathrm{Hg}$ ) found are present in small amounts and still below accepted standards. Some beneficial microelements for plant growth such as $\mathrm{Fe}, \mathrm{Co}$, and $\mathrm{Mn}$ are detected in varying quantities. For bacteriological characteristics, both of total and fecal coliforms are identified in sewage sludge with $8.1 \times 10^{3}$ and $1.1 \times 10^{3} \mathrm{cfu} / \mathrm{g}$, respectively, but we have noticed an absence of Salmonella.
\end{abstract}

Keywords: Sewage sludge; Domestic sewage; Microelement; Major nutrient; Heavy metal; Agriculture

\footnotetext{
${ }^{*}$ Corresponding author.
} 


\section{Introduction}

In order to promote the agricultural sector in Algeria, researchers focus their study on valorization of residual sludge from wastewater treatment plants for agricultural purposes. The National Sanitation Office (ONA) in Algeria produces increasing quantities of sludge; only $25 \%$ of sludge is used in agriculture, whereas $60 \%$ is landfilled [1]. About 177 wastewater treatment plants currently produce some 120,000 tons, particularly rich in organic matter. However, the organic matter rate in Algerian agricultural soil is dramatically low due to the Mediterranean climate characterized by relatively high temperatures in spring and autumn, which leads to a high mineralization of organic matter. In fact, soil bacteria decompose organic matter more quickly at high temperatures in the presence of moisture and oxygen [2]. In addition, some intensive agricultural practices can be responsible for soil degradation and the reduction of organic matter levels.

The agronomic value of the sewage sludge depends mainly on its content in macro and microelements. Sewage sludge contains valuable components such as organic matter, N, P, and other plant nutrients, consequently its disposal by application to land becomes increasingly used [3]. It is considered as a rich source of organic matter that helps to improve various several soil properties, including bulk density, porosity, and water-holding capacity $[3,4]$. The experimental results of Wołejko et al. [5] showed that the use of sewage sludge as fertilizer is recommended for urban soils which have an advanced degradation degree. The fertilizing aspect attributed to sewage sludge always improves soil fertility over time [6]. Using the sludge as a suitable product for minerals fertilizers may reduce the intensive consumption of commercial fertilizers. The use of sludge to increase soil fertility not only provides nutrients for crops, but may eliminate the need for commercial fertilizers [7]. In general, nutrient levels in sewage sludge are low compared with commercial fertilizers, to compensate for this deficit; sewage sludge can be combined with commercial fertilizers to get optimal nutrient contents that are suitable for plants growth $[8,9]$.

\section{Materials and methods}

\subsection{Region location, agricultural activity, and climate}

Jijel is located on the north-eastern coast of Algeria $\left(36^{\circ} 49^{\prime} \mathrm{N} 5^{\circ} 46^{\prime} \mathrm{E}\right)$ extending over an area of 239,103 ha. Thanks to favorable climatic and soil conditions; agriculture is the main economic activity with a diversified production system. $18.2 \%$ of total area is useful agricultural grounds exploited for different kinds of cultures: market gardening (15.3\%), forage crops $(37 \%)$, olive cultivation $(39 \%)$, arboriculture $(6.8 \%)$, cereals $(2.3 \%)$, and vegetables $(1 \%)$. The mountainous areas managed following normal intensive agronomic practice with the predominance of olive cultivation and the plain areas are mainly used for market gardening, hence the use of chemical fertilizers is relatively high.

According to the data collected from the National Meteorological Office (ONM) located at Jijel Airport between 1990 and 2010, the region has a Mediterranean climate characterized by mild, rainy winters and hot, humid summers with an average annual rainfall of $986 \mathrm{~mm}$. The average monthly temperature ranges between $11.5^{\circ} \mathrm{C}$ in January and $26.2^{\circ} \mathrm{C}$ in August. The humidity is relatively high and varies between $78.1 \%$ and $71.6 \%$.

\subsection{Treatment plant processes}

The wastewater treatment plant is located on the western side of Jijel city; it was brought into service in June 2008. It has activated-sludge treatment processes with high aeration rate, designed to treat domestic wastewater of the city and its surroundings. Daily volume arriving at the plant is about $11,000 \mathrm{~m}^{3} / \mathrm{d}$ with a maximum capacity of $30,000 \mathrm{~m}^{3} / \mathrm{d}$. The treatment plant was dimensioned for a 150,000 inhabitants equivalent capacity and was equipped with 18 drying beds. The amount of sludge produced per month is about $213 \mathrm{~m}^{3}$ (equivalent to 64.5 tons of dry matter).

\subsection{Samples}

Several samples of dried sludge were taken from the treatment plant drying beds and were then stored in a refrigerator at about $4^{\circ} \mathrm{C}$ in order to avoid any change in the physicochemical characteristics. Moisture was removed by natural dewatering, which consists in spreading the thickened sludge over rectangular areas $(15 \mathrm{~m} \times 30 \mathrm{~m})$ in superimposed layers with a thickness not exceeding $50 \mathrm{~cm}$, to increase sludge exposed area to evaporation effects and to facilitate gravity filtration through sand and gravel grains.

\subsection{Physicochemical analysis}

The $\mathrm{pH}$ and electrical conductivity were measured at a sludge/water ratio of 1:2.5 and 1:5 using a $\mathrm{pH}$ meter and conductivity meter, respectively. Moisture was determined by the oven drying method at $105^{\circ} \mathrm{C}$ during $24 \mathrm{~h}$. Total nitrogen was determined by the Kjeldahl method. The organic carbon analysis was carried out by Walkley and Black procedure. The total calcium carbonate content $\left(\mathrm{CaCO}_{3}\right)$ was measured using a Bernard calcimeter [10]. Phosphorus, potassium, magnesium, calcium, sulfur, and total heavy metals were determined after digestion with nitric acid $\left(\mathrm{HNO}_{3}\right)$, hydrogen peroxide $\left(\mathrm{H}_{2} \mathrm{O}_{2}\right)$, and hydrochloric acid $(\mathrm{HCl})$ [11] Phosphorus was determined colorimetrically. Sulfur and potassium were, respectively, measured by turbidimetry and flame photometry. Mercury was detected by the cold vapor atomic absorption spectrometry technique, and the remaining trace elements were analyzed by atomic absorption spectrometry.

\subsection{Bacteriological analysis}

The Salmonella detection results were expressed qualitatively (presence or absence). Concerning the determination of total and fecal coliforms, the sludge samples were diluted (1:10) with $90 \mathrm{~mL}$ of phosphate buffer $(\mathrm{pH}=7.2)$, followed by a good agitation to homogenize the contents before proceeding with the analysis using the membrane filtration method [12,13]. Physicochemical and bacteriological analysis are presented in Table 1 
Table 1

Physicochemical and bacteriological properties of dried sewage sludge

\begin{tabular}{lll}
\hline Parameters & Average & Standard (NFU 44-095) [18] \\
\hline Moisture $(\%)$ & $35.7(3.6)$ & $<50$ \\
$\mathrm{pH}$ & $6.6(0.3)$ & - \\
Electrical conductivity $\left(\mathrm{dS} \mathrm{m}{ }^{-1}\right)$ & $0.83(0.05)$ & - \\
$\mathrm{C} / \mathrm{N}$ & 11.8 & - \\
Organic matter $(\% \mathrm{dw})$ & $41.19(2.41)$ & $>30$ \\
Total organic carbon $(\% \mathrm{dw})$ & $26.42(2.27)$ & $<3$ \\
Total nitrogen $(\% \mathrm{dw})$ & $2.23(0.52)$ & $<3$ \\
Total phosphorus $(\%)$ & $1.5(0.2)$ & - \\
Calcium carbonate $(\% \mathrm{dw})$ & $5.79(1.16)$ & - \\
Calcium $(\% \mathrm{dw})$ & $1.53(0.14)$ & - \\
Potassium $(\mathrm{g} / \mathrm{kg} \mathrm{dw})$ & $3.82(0.48)$ & - \\
Magnesium $(\mathrm{g} / \mathrm{kg} \mathrm{dw})$ & $1.4(0.33)$ & - \\
Sulfur $(\mathrm{g} / \mathrm{kg} \mathrm{dw})$ & $3.1(0.61)$ & - \\
Iron $(\mathrm{g} / \mathrm{kg} \mathrm{dw})$ & $11.6(0.4)$ & - \\
Cobalt $(\mathrm{mg} / \mathrm{kg} \mathrm{dw})$ & 120 & $<12$ \\
Manganese $(\mathrm{mg} / \mathrm{kg} \mathrm{dw})$ & 360 & $<2$ \\
Selenium $(\mathrm{mg} / \mathrm{kg} \mathrm{dw})$ & 1.32 & - \\
Mercury $(\mathrm{mg} / \mathrm{kg} \mathrm{dw})$ & 0.73 & $<10^{3}$ (represented by Escherichia coli) \\
Bacterial indicators & & Absence \\
Total coliforms $(\mathrm{cfu} / \mathrm{g})$ & $8.1 \times 10^{3}$ & \\
Fecal coliforms $(\mathrm{cfu} / \mathrm{g})$ & $1.1 \times 10^{3}$ & Absence \\
Salmonella $(\mathrm{cfu} / 25 \mathrm{~g})$ & & \\
\hline
\end{tabular}

dw, dry weight.

\section{Results and discussion}

\subsection{Standards and regulations of amendment spreading in Algeria}

The absence of regulatory texts governing the agricultural use of sewage sludge in Algeria, calls for the adoption of the NFU 44-041 (French standard) related to denominations and specifications of sludge resulting from water treatment as fertilizer material. As this standard was withdrawn in August 2012, we should therefore refer to the NFU 44-095 standard approved in May 2002 on organic amendments and composts from the wastewater treatment plant containing substances of agricultural value [14].

\subsection{Evaluation of physicochemical properties of sewage sludge for agricultural uses}

\subsection{1. $\mathrm{PH}$, electrical conductivity, and organic matter}

The sewage sludge is relatively acidic with an average $\mathrm{pH}$ of 6.6. The spreading of sludge generally leads to a change in soil $\mathrm{pH}$ and affects nutrient solubility, which is considered as a factor determining the availability of nutrients needed for plant growth. It is recommended that soil $\mathrm{pH}$ should be maintained above 6.5 for sludge-amended soils [15]. This sludge is in a favorable $\mathrm{pH}$ range between 6 and 7 which does not require lime stabilization when it is applied to soils near to neutrality.

According to Durand's classification [16], the sludge is classified as slightly salty substrate with an electrical conductivity (EC) average of $0.83 \mathrm{dS} \mathrm{m} \mathrm{m}^{-1}$, this value indicates that the use of the sludge is favorable for most crops. High soil salinity is a critical factor that limits plant growth and productivity [17]. However, the application of sewage sludge also increases the electrical conductivity of soils due to the high level of salts in sludge [18].

The application of organic matter improves soil properties such as moisture retention, soil structure, and nutrient dynamics, which positively influences crops yield. In addition, organic matter decomposition promotes crops rooting and supplies essential plant nutrients; it increases the availability of nitrogen and phosphorus fractions and can then provide a new source of nourishment for earthworms and microorganisms [19]. As well, sewage sludge from drying beds is rich in organic matter ranging from $35 \%$ to $52.7 \%$ with an average of $41.2 \%$, therefore it is considered as soil amendment rather than an organic fertilizer.

\subsubsection{Nutrient contents}

Sewage sludge contains significant amounts of major nutrients with a total nitrogen content of $2.23 \%$ and a total phosphorus content of $1.5 \%$; they play an essential role in soil fertilization and plant growth. However, plants require important quantities of nitrogen from 20 to $320 \mathrm{~kg} / \mathrm{ha}$ per year, depending on plants variety [20]. The dose of sewage sludge applied to soil depends often on the rate of nitrogen that contains [18]. Phosphorus contained in sewage sludge can solve many problems for local farmers especially as the consumption of phosphate fertilizers is continuously 
increasing. Phosphorus input from sewage sludge is crucial for crops growth; it is involved in photosynthesis, cell division, and synthesis of enzymes and proteins. Unlike nitrogen, phosphorus is relatively immobile in the soil. The phosphorus requirements of agricultural crops can range from 30 to $80 \mathrm{~kg} / \mathrm{ha}$ per year [20]. Whereas the potassium content in the sewage sludge from Jijel treatment plant was $0.39 \%$, some reported results showed that the potassium level in sludge is generally low and can range from $0.08 \%$ to $1.10 \%$, but is still sufficient for plant uptake [21].

The secondary nutrients $(\mathrm{Mg}, \mathrm{S})$ are relatively less important than the major ones; they are present in sludge in relatively small amounts of 1.4 and $3.1 \mathrm{~g} / \mathrm{kg}$ respectively. Usually, plants require moderate amounts of secondary nutrients. The calcium carbonate content in the sludge is $5.8 \%$, which can facilitate the infiltration of irrigation water without risk of clogging. It is also considered as the most frequent source of calcium required for plants edification. The experimental result of spreading sewage sludge on the forest soil in Algeria showed that the concentration of $\mathrm{Ca}$ and $\mathrm{Mg}$ increases with the increase in sludge rate [22].

\subsection{3. $\mathrm{C} / \mathrm{N}$ ratio}

The $\mathrm{C} / \mathrm{N}$ ratio is an index of the easily mineralizable organic nitrogen fraction in municipal sludge and uncomposted farm manure [23]. According to the analysis results, the dried sludge contains $26.4 \%$ of organic carbon and $2.2 \%$ of nitrogen with a $\mathrm{C} / \mathrm{N}$ ratio of 11.8 ; this allows assessment of the nitrogen mineralization potential. However, organic fertilizers with a $\mathrm{C} / \mathrm{N}$ ratio lower than 20 have a high mineralization rate and can release significant amounts of nitrogen into crops [24].

\subsubsection{Evolution of heavy metals content}

The sludge applied to fertilize agricultural soils frequently contains high concentrations of harmful heavy metals that can be transmitted in the food chain and, because of their high toxicity, present a real threat to crop production and animal and human life [25]. However, metal concentrations in sewage sludge depend on the origin of sewage transported and sludge pretreatment processes followed [26]. It is essential to check the concentrations of heavy metals in the sludge before its spreading on agricultural lands $[27,28]$. Although some microelements, in particular, Fe, Mn, B, Zn, and $\mathrm{Cu}$, are essential for plant growth at concentration limits that should not be exceeded.
Some dried sludge compounds are present in variable concentrations, we have significant amounts of iron $(1.16 \%)$ and low rates of $\mathrm{Mn}, \mathrm{Zn}, \mathrm{Cu}$, and $\mathrm{Co}$; these results are presented in Tables 1 and 2 . The supply of these microelements by sewage sludge can be useful in the case where soils are depleted for their natural minerals or to boost crop yields.

The evolution of harmful heavy metals concentration over the last years is presented in Table 2. Since the treatment plant was brought into service in June 2008, we have found a small change in the concentration of each metal from year to year. The average concentrations obtained of $\mathrm{Cd}, \mathrm{Cr}, \mathrm{Cu}$, $\mathrm{Ni}, \mathrm{Pb}, \mathrm{Hg}$, and Se are below the established standards (NFU 44-095), except for zinc ( $\mathrm{Zn}$ ) which slightly exceeded the recommended limits with an average of $613 \mathrm{mg} / \mathrm{kg}$. The low levels of harmful heavy metal found for this type of sewage sludge are strongly related to the wastewater origin. In general, only domestic sewage is transported to Jijel treatment plant because the existing industrial facilities are located far from sewerage treatment plant systems. However, the high concentration of zinc in sewage sludge can be explained by corrosion and leaching of plumbing into wastewater and cosmetics and paint discharges.

\subsection{Bacteriological characteristics}

Different types of pathogen, including bacteria that can cause diseases to human and animal lives, are generally present in wastewater and raw sewage sludge, their level of presence often depends on the reductions realized through the wastewater and sewage sludge treatment processes. These microorganisms can cause a huge risk to public health if they are transferred to food crops grown in sludge-amended soils. Furthermore, they can be transported away from the site by other factors such as insects, rodents, and birds [9].

Bacteriological analyses (Table 1) revealed the existence of fecal indicator $\left(1.1 \times 10^{3} \mathrm{cfu} / \mathrm{g}\right)$ and total coliforms $\left(8.1 \times 10^{3} \mathrm{cfu} / \mathrm{g}\right)$ with an absence of Salmonella. According to established standards (NFU 44-095), sewage sludge used for agricultural fertilization purposes and land reclamation should be free of Salmonella, but the threshold limit for Escherichia coli (represented by fecal indicator) for all crops is $10^{3} \mathrm{cfu} / \mathrm{g}$.

Salmonella is considered to be one of the most hygienically problematic microorganisms, as it is a potential bacterium with a high growth capacity [29]. However, it was not detected in our sewage sludge. When sludge contains fecal coliform below $1,000 / \mathrm{g}$ solid, the presence of Salmonella is generally not detected [30].

Table 2

Variation of heavy metal concentrations in sewage sludge between 2008 and 2016

\begin{tabular}{|c|c|c|c|c|c|c|c|c|c|c|}
\hline Heavy metals $(\mathrm{mg} / \mathrm{kg})$ & 2008 & 2009 & 2010 & 2011 & 2012 & 2013 & 2014 & 2015 & 2016 & Standard (NFU 44-095) \\
\hline Cadmium (Cd) & $<6$ & 1 & 1 & 0.77 & 1.5 & 1.27 & 1 & 2 & 1 & 3 \\
\hline Zinc $(\mathrm{Zn})$ & 526 & 650 & - & 609.2 & 728 & 617.3 & 594 & 631 & 549 & 600 \\
\hline Chrome (Cr) & 110 & 50 & 35 & 39.3 & 42.8 & 85.1 & 61.5 & 50 & 57 & 120 \\
\hline Copper $(\mathrm{Cu})$ & 110 & 108 & 90 & 105.7 & 144 & 114.4 & 126 & 123 & 112 & 300 \\
\hline Nickel (Ni) & $<40$ & - & 21 & 20.1 & 30.9 & 34.1 & 29 & 29 & 27 & 60 \\
\hline Lead $(\mathrm{Pb})$ & 79 & 134 & 67 & - & - & 127.5 & 122 & 120 & 86 & 180 \\
\hline
\end{tabular}


Table 3

Nutrients rate of sewage sludge and commercial fertilizers (ton/year)

\begin{tabular}{lccccl}
\hline & Quantity & $\mathrm{N}$ & $\mathrm{P}_{2} \mathrm{O}_{5}$ & $\mathrm{~K}_{2} \mathrm{O}$ & $\mathrm{SO}_{3}$ \\
\hline Dried sludge & 774 & 17.26 & 11.61 & 2.99 & 2.39 \\
Fertilizer 1 (NPK) & $1,075.3$ & 118.3 & 161.3 & 161.3 & - \\
Fertilizer 2 (PK) & 85.4 & - & 17.1 & 21.3 & - \\
Fertilizers 3 & 19.4 & - & - & 9.7 & 8.9 \\
(Potassium sulfate) & & & & & \\
\hline
\end{tabular}

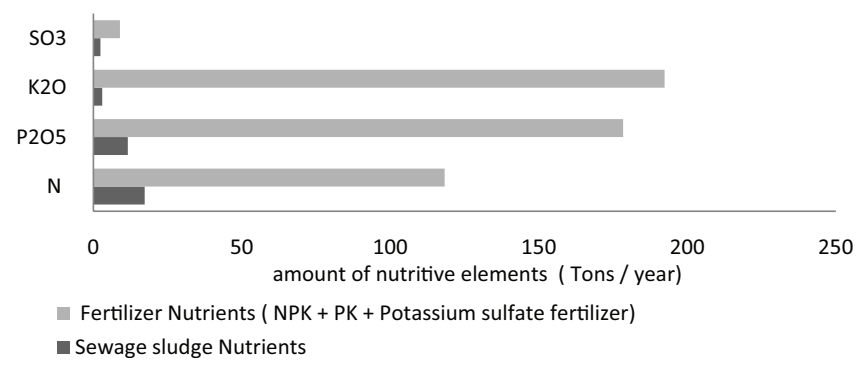

Fig. 1. Total amount of nutrients obtained by sewage sludge and $52 \%$ of commercial fertilizers (per year).

\subsection{Comparison between sewage sludge and commercial fertilizers in nutrients supply}

The amount of sludge produced by Jijel wastewater treatment plant is approximately $213 \mathrm{~m}^{3}$ per month (equivalent to 64.5 tons of dry matter). This large quantity of sewage sludge, about 774 tons per year, is considered as an untapped source of fertilization, it is always intended to be landfilled. The investigation report on fertilizer consumption in Jijel region indicates that nitrogen, phosphorus and potassium (NPK) fertilizers are the most widely used (47.2\%), while phosphorus and potassium (PK), and potassium sulfate fertilizers represent $4.6 \%$. These three fertilizers represent almost $52 \%$, or the equivalent of 1180.1 tons per year of total commercial fertilizers used by local farmers

A comparison is presented in Table 3 between nutrient amounts (N, P, K, and S) in commercial fertilizers (NPK, PK, and potassium sulfate) used and major nutrients, which can be obtained from the sewage sludge generated by the treatment plant.

Fig. 1 shows the theoretical inputs of major nutrients obtained by sewage sludge. Nutrients are presented in varying amounts with 17.26 tons of $\mathrm{N}, 11.61$ tons of $\mathrm{P}_{2} \mathrm{O}_{5}, 2.99$ tons of $\mathrm{K}_{2} \mathrm{O}$, and 2.39 tons of $\mathrm{SO}_{3^{\prime}}$, which are relatively low compared with the total nutrients provided by commercial fertilizers (NPK, PK, and potassium sulfate).

The nutrient ratios (sludge/fertilizers) are varying from one nutrient to another with $26.8 \% \mathrm{SO}_{3^{\prime}} 14.6 \% \mathrm{~N}, 6.5 \%, \mathrm{P}_{2} \mathrm{O}_{5^{\prime}}$ and $1.5 \% \mathrm{~K}_{2} \mathrm{O}$. These ratios show the difference in nutrients amount that can be supplied by sewage sludge compared to about $52 \%$ of total nutrients consumed in Jijel.

\section{Conclusion}

Before any use of sewage sludge for agricultural purposes, it must be characterized in order to assess its potential for nutrient supplementation and to avoid the usual risk of crops contamination. The sludge samples taken from drying beds of Jijel wastewater treatment plant were subjected to physicochemical, bacteriological, and toxicological analyses, this study enabled us to draw the following conclusions:

The organic matter content is high, ranging from $35 \%$ to $52.7 \%$ with a $\mathrm{C} / \mathrm{N}$ ratio of 11.8 indicating that the mineralization of the organic matter will be started shortly after sludge spreading, thus making nitrogen quantities readily available to crops.

The tested sludge from drying beds does not contain Salmonella bacteria, but it contains both of total and fecal coliforms at concentrations within acceptable limits for agricultural uses, however, they do not present a potential risk unlike Salmonella. They can be eliminated at temperatures above $55^{\circ} \mathrm{C}$ [29].

Most concentration levels of harmful heavy metals in the sewage sludge were below the established standards (NFU41-095) between 2008 and 2016, except for zinc (Zn) which slightly exceeded the recommended limits.

The content of sewage sludge in major nutrients $(\mathrm{N}, \mathrm{P}$, $\mathrm{K}, \mathrm{S}$ ) is low compared with mineral fertilizers. But, it also contains appreciable levels of secondary nutrient and some microelements that play an essential role in increasing plant yields.

Landfilling is currently the main route for the disposal of sewage sludge in Jijel. On the other hand, it was found that the organic matter content was high and most of the physicochemical and bacteriological characteristics including heavy metals, all comply with the regulatory standards for organic amendments (NFU 41-095); the dried sludge can therefore be safely used as a soil amendment as an alternative to landfilling that generates potential environmental hazards, including the emission of odor and methane gas.

However, negative effects such as the accumulation of heavy metals in soil resulting from the long-term use of sludge in the future must be taken into account and annual monitoring is therefore recommended in the context of sustainable agriculture.

Finally, the dried sludge often contains low rate of major nutrients and some beneficial microelements that are not found in commercial fertilizers. It may therefore constitute a valuable substrate which can be combined with fertilizers to get optimal nutrient contents for each type of culture; it would be interesting to explore this approach in a subsequent study.

\section{References}

[1] D. Bleaid, Use of Residual Sludge from Wastewater Treatment Plants in Algeria, Agronomic Report Collection, Algeria, 2015. Available at: http://www.djamel-belaid.fr/app/ download/25250901/LivreBoueR\%C3 \%A9siduelle.pdf.

[2] A. Boutmedjet, N. Boukaya, Z. Houyou, M.L. Ouakid, C. Bielders, Study of the Effects of Sewage Sludge Application on Eroded Cultivated Soil in the Laghouat Region, Vol. 36, Revue des Régions Arides-Numéro Spécial-n., 2015.

[3] R.P. Singh, M. Agrawal, Potential benefits and risks of land application of sewage sludge, Waste Manage., 28 (2008) 347-358.

[4] S. Karef, A. Kettab, M. Nakib, Characterization of byproducts from wastewater treatment of Medea (Algeria) with a view to agricultural reuse, Desal. Wat. Treat., 52 (2014) 2201-2207.

[5] E. Wołejko, A. Butarewicz, U. Wydro, T. Łoboda, Advantages and potential risks of municipal sewage sludge application to urban soil, Desal. Wat. Treat., 52 (2014) 3732-3742. 
[6] R.P. Singh, M. Agrawal, Use of sewage sludge as fertilizer supplement for Abelmoschus esculentus plants: physiological, biochemical and growth responses, Int. J. Environ. Waste Manage., 3 (2009) 91-106.

[7] R.P. Singh, P. Singh, M.H. Ibrahim, R. Hashim, Land application of sewage sludge: physicochemical and microbial response., Rev. Environ. Contam. Toxicol., 214 (2012) 41-61.

[8] E.P. Pakhnenko, A.V. Ermakov, L.L. Ubugunov, Influence of sewage sludge from sludge beds of Ulan-Ude on the soil properties and the yield and quality of potatoes, Moscow Univ. Soil Sci. Bull., 64 (2009) 175-181.

[9] R.D. Tyagi, R.Y. Surampalli, S. Yan, T.C. Zhang, C. M. Kao, B.N. Lohani, Sustainable Sludge Management: Production of Value Added Products, American Society of Civil Engineers Publications, Reston, VA, 2009.

[10] C. Mathieu, F. Pieltain, Analyse chimique des sols: Méthodes choisies, éd. tec et doc, Paris, 2003.

[11] US Environmental Protection Agency, Method 3050B: Acid Digestion of Sediments-Sludges and Soils, Test Methods for Evaluating Solid Waste, Washington, D.C., USA, 1996.

[12] Center of Expertise in Environmental Analyzes of Quebec, Detection and Count of Total Coliform: Membrane Filtration Method, MA700-Col 1.0, Quebec, 2003.

[13] Center of Expertise in Environmental Analyzes of Quebec, Detection and Count of E. coli and Fecal Coliform: Membrane Filtration Method, MA. 700 - fec.ec 1.0, Rev. Ed., Quebec, 2014.

[14] French Standards Association (AFNOR), NF U44-095 Standard: Organic Amendments-Composts Containing Substances of Agronomic Interest from Water Treatment, Paris, 2002.

[15] B.J. Henning, H.G. Snyman, T.A.S. Aveling, Plant-soil interactions of sludge-borne heavy metals and the effect on maize (Zea mays L.) seedling growth, Water SA, 27 (2001) 71-78.

[16] J.H. Durand, Les Sols Irrigables: etude pedologique, Presses Universitaires de France, Paris, 1983.

[17] A.K. Parida, A.B. Das, Salt tolerance and salinity effects on plants, Ecotoxicol. Environ. Saf., 60 (2005) 324-349.

[18] J.S. Mtshali, A.T. Tiruneh, A.O. Fadiran, Characterization of sewage sludge generated from wastewater treatment plants in Swaziland in relation to agricultural uses, Resour. Environ., 4 (2014) 190-199.

[19] A. N'Dayegamiye, A. Drapeau, S. Huard, Y. Thibeault, Intégration de boues mixtes et de fumiers dans des rotations agricoles: Réponse des cultures et interactions avec les propriétés du sol, Agrosol, 15 (2004) 83-90.
[20] M. Nakib, A. Kettab, A. Berreks, L. Mandi, Study of the prospects for agricultural utilization of sludge produced from WWTPS in North Central Algeria, Desal. Wat. Treat., 55 (2015) $1152-1166$.

[21] L.E. Sommers, Chemical composition of sewage sludge and analysis of their potential use as fertilizers, J. Environ. Qual., 6 (1977) 225-232.

[22] S. Igoud, Valorisation des boues résiduaires issues des stations d'épuration urbaines par leur épandage dans les plantations forestières, Rev. Energ. Ren : Production et ValorisationBiomasse -Numéro Spécial-n., (2001) 69-74.

[23] M. Hébert, Epandage automnal des MRF: risques environnementaux et mesures préventives, Agrosol, 16 (2005) 61-78.

[24] M. Bipfubusa, A. N’Dayegamiye et H. Antoun, Évaluation des effets de boues mixtes fraîches et de leurs composts sur les rendements des cultures et leur nutrition minérale., Agrosol, 17 (2006) 65-72.

[25] M.K. Jamali, T.G. Kazi, M.B. Arain, H.I. Afridi, N. Jalbani, G.A. Kandhro, A.Q. Shah, J.A. Baig, Heavy metal accumulation in different varieties of wheat (Triticum aestivum L.) grown in soil amended with domestic sewage sludge, J. Hazard. Mater., 164 (2009) 1386-1391.

[26] N.V. Hue, S.A. Ranjith, Sewage sludges in Hawaii: chemical composition and reactions with soils and plants, Water Air Soil Pollut., 72 (1994) 265-283.

[27] J. Dai, L. Chen, J. Zhao, N. Ma, Characteristics of sew age sludge and distribution of heavy metal in plants with amendment of sewage sludge, J. Environ. Sci., 18 (2006) 1094-1100.

[28] E. Włodarczyk, L. Wolny, P. Wolski, Evaluation of dewatered sludge properties from a selected municipal sewage treatment plant, Desal. Wat. Treat., 52 (2014) 3852-3858.

[29] V. Banegas, J.L. Moreno, J.I. Moreno, C. Garcia, G. Leon, T. Hernandez, Composting anaerobic and aerobic sewage sludges using two proportions of sawdust, Waste Manage., 27 (2007) 1317-1327.

[30] U.S. Environmental Protection Agency, Environmental Regulations and Technology: Control of Pathogens and Vector Attraction in Sewage Sludge, EPA/625/R-92/013, Rev. Ed., USEPA, Cincinnati, OH, 2003. 